九州大学学術情報リポジトリ

Kyushu University Institutional Repository

\title{
Cost and Efficiency of Milk Hauling
}

Kobayashi, Kohei

Department of Agricultural Economics, Faculty of Agriculture, Kyushu University

Sawada, Shujiro

Department of Agricultural Economics, Faculty of Agriculture, Kyushu University

https://doi.org/10.5109/22822

出版情報: 九州大学大学院農学研究院紀要. 17 (1)，pp. 105-118，1972-08. Kyushu University バージョン：

権利関係 : 
J. Fac. Agr., Kyushu Univ., 17, 105-118 (1972)

\title{
Cost and Efficiency of Milk Hauling
}

\author{
Kohei Kobayashi* and Shujiro Sawada \\ Department of Agricultural Economics, Faculty of Agriculture, \\ Kyushu University, Fukuoka
}

(Received December 5, 1971)

\begin{abstract}
In Japan, the number of cows per dairy farm is still so small that milk has to be collected at collecting stations first, and shipped to a factory. In the case of a large milk shed in Fukuoka Prefecture, the hauling and shipping cost was calculated through investigation. It was considerably high. By an econometric method, it was made clear how the cost could be minimized by decreasing the number of and enlarging the scale of collecting stations under the can- and the bulk-hauling systems.
\end{abstract}

\section{INTRODUCTION}

In Japan, the can-hauling is still common for transporting milk from farmers to processing plants. However, for the process between collecting stations and processing plants, the bulk-hauling has been gaining importance. Bulk-tanks have been installed at collecting stations, and tank-trucks replacing can-trucks in the hauling process. In Kyushu where milk handling needs special care because of the high temperature and humidity, 17.4 per cent of collecting stations were equipped with bulk-tanks in 1966, while the percentage was only 3.5 for the whole country at the same date as shown in Table 1.

Farmers bring their own milk each to their neighboring collecting stations. For that, they use their own traditional $l$-to** milk-cans and various kinds of vehicles. The milk is cooled there and waits for the further transportation. Two alternative methods are used for cooling and transportation. Under the “can-hauling system", farmers' milk is poured into co-ops' 2-to milk-cans at the stations, as farmers' cans are too small. These cans are dipped into water cooled by the refrigerator and handed over to the pick-up truck. Under the "bulk-hauling system", farmers' milk is dumped into the bulk tank at the station, and cooled there. Then the milk is pumped up by the tank truck and hauled to the processing plant.

In a specified milkshed, there is a close relation among the number of collecting stations, their size, the distance from farms to collecting stations and the length of pick-up truck routes. If the whole amount of milk shipped remains constant, the greater the number of collecting stations, the smaller the

* Present address: Kyushu Branch of National Research Institute of Agricultural Economics, Ministry of Agriculture and Forestry, Fukuoka.

The authors are greatly indebted to Professor K. Tsuchiya for his valuable comments. They also owe much to Mr. S. Kobae who helped them with the laborious field works. ** l-to is equivalent to 18.05 liters or 4.76 gallons. 10-to is 1 -koku. 1-to is 10-sho. 
Table 1. Collecting stations classified in types (Precentage, 1966).

\begin{tabular}{|c|c|c|c|c|c|c|}
\hline Agricultural district & $\begin{array}{l}\text { No apparatus } \\
\text { except weigh- } \\
\text { ing machine }\end{array}$ & $\begin{array}{l}\text { Water tank } \\
\text { for cooling } \\
\text { cans }\end{array}$ & $\begin{array}{l}\text { Water tank } \\
\text { for cooling } \\
\text { cans with } \\
\text { sefrigerater }\end{array}$ & $\begin{array}{l}\mid \text { Surface } \\
\text { cooler, and } \\
\text { milk tank } \\
\text { for storage: }\end{array}$ & I3ulk cooler & Total \\
\hline $\begin{array}{l}\text { Hokkaido } \\
\text { Tohoku } \\
\text { Kanto } \\
\text { Hokuriku } \\
\text { Tozan } \\
\text { Tokai } \\
\text { Kinki } \\
\text { Chugoku, Shikoku } \\
\text { Kyushu } \\
\text { Whole c o u try }\end{array}$ & $\begin{array}{l}33.3 \\
15.8 \\
49.0 \\
15.6 \\
49.0 \\
25.3 \\
35.1 \\
59.4 \\
19.1 \\
42.6\end{array}$ & $\begin{array}{l}59.7 \\
79.0 \\
35.4 \\
63.1 \\
35.4 \\
34.5 \\
17.7 \\
21.8 \\
5.0 \\
34.0\end{array}$ & $\begin{array}{c}0 \\
2.6 \\
14: 0 \\
18.3 \\
14.0 \\
34.3 \\
43.3 \\
15.5 \\
58.5 \\
19.9\end{array}$ & $\begin{array}{l}7.0 \\
0.9 \\
0.7 \\
2.7 \\
0.7 \\
2.4 \\
2.0 \\
2.0 \\
5.5 \\
1.5\end{array}$ & $\begin{array}{r}0 \\
1.7 \\
0.9 \\
3.3 \\
0.9 \\
3.5 \\
1.9 \\
1.3 \\
11.9 \\
2.0\end{array}$ & $\begin{array}{l}100 \\
100 \\
100 \\
100 \\
100 \\
100 \\
100 \\
100 \\
100 \\
100\end{array}$ \\
\hline
\end{tabular}

Source: Present Situations of Milk Hauling and Dairy Industry (Shūnyū to Nyūgyō no Genjö), Ministry of Agriculture and Forestry, mimeographed, 1967.

size of a station, and the shorter the distance from farms to collecting stations, but the longer the pick-up truck routes. If the whole amount of milk shipped changes, the cost at each stage will be changed. Accordingly, the total cost of hauling composed of three parts, i. e., (a) the shipping cost from farms to collecting stations, (b) the handling cost at the stations, and (c) the hauling cost from the stations to a processing plant, will be affected mainly by the number of collecting stations and the amount of milk shipped.

\section{PURPOSE OF STUDY}

This is a case study of a milkshed located in northern Kyushu for the purposes of (1) to estimate the hauling cost at the three different stages of hauling as stated above, (2) to estimate two kinds of optimums, i. e., (i) the optimum number and size of collecting stations under the can and the bulk hauling systems respectively to minimize the average hauling cost, assuming the whole amount of milk shipped being unchanged, and (ii) the optimum number and size of collecting stations, and the optimum amount of milk shipped, assuming that the latter can be changed, to minimize the average hauling cost.

\section{INVESTIGATION}

The milksheds investigated are located in Fukuoka Prefecture and cover the north-western and southern parts of this prefecture. The north-western area is centralized by Fukuoka, and the southern area by Kurume. Fukuoka is commercial city, and had a population of 749,808 in 1964 . Kurume is an industrial city where rubber and many related factories are located. It had a population of 158,974 in 1964 . We may call these two areas Fukuoka and Kurume milksheds.

Necessary data were obtained through interviews and records for the 12 month period from September, 1964 to August, 1965. In this milkshed, there were 885 dairy farms, 127 collecting stations and 25 pick-up routes. Out of these, 281 dairy farms, 67 collecting statitos and 15 pick-up truck routes were selected for investigation as follows. Only all pick-up routes managed by a co-op were 
investigated. The number of the routes was 15. Along the each route, collecting stations were selected alternately. Farmers investigated were selected at random among each group of farmers shipping their milk to each collecting station in proprotion to the number of farmers of the group, taking the total number of farmers sampled as 270 to 290 which might be enough for analyzing the results of the investigation for our study from the statistical point of view. A large co-op, Fukuoka Federation of Dairy Co-operatives (FFDC), covers the entire area. The milk is collected daily and shipped to a processing plant of Yukijirushi (Snow Brand) Milk Co. Ltd. which is one of the three largest milk companies in Japan.

To get data necessary to infer the effect of introducing the bulk hauling system into this area, a milkshed in Kumamoto Prefecture was investigated where the bulk hauling system was already adopted. In Kumamoto Prefecture, there were 18 large collecting stations with bulk tanks, which were located in the major dairy regions, and 18 associated pick-up routes. Out of them, 14 stations and 18 associated pick-up routes were sampled and investigated.

\section{RESULTS OF INVESTIGATION}

Before analyzing the data we got, some general situation of the dairy investigated is stated here.

\section{Dairy Farms}

All farmers investigated are shown in Table 2. They are classified into two categories, the amount of milk shipped per farm per year and the distance from

Table 2. Number of investigated farms and their cows classified.

\begin{tabular}{|c|c|c|c|c|c|}
\hline \multirow{2}{*}{$\begin{array}{l}\text { Amount of } \\
\text { milk shipped } \\
\text { (ton) }\end{array}$} & \multirow{2}{*}{$\begin{array}{l}\text { Distance from } \\
\text { farm to collecting } \\
\text { stations } \\
\text { (kilometer) }\end{array}$} & \multirow{2}{*}{$\begin{array}{l}\text { Number of } \\
\text { investigated } \\
\text { farms }\end{array}$} & \multicolumn{3}{|c|}{ Number of cows and heifers per farm } \\
\hline & & & Cows & Heifers & Total \\
\hline $\begin{array}{c}\text { S } \\
\text { (less than 10) }\end{array}$ & $\begin{array}{l}\text { A }(\text { less than } 1) \\
\mathrm{B}(1-3) \\
\mathrm{C}(2-3) \\
\mathrm{D}(\text { over } 3)\end{array}$ & $\begin{array}{r}36 \\
21 \\
12 \\
4\end{array}$ & $\begin{array}{l}2.7 \\
2.6 \\
2.8 \\
3.6\end{array}$ & $\begin{array}{ll}0.6 & \\
0 & 9 \\
0.8 & \\
0.8 & \end{array}$ & $\begin{array}{l}3.3 \\
3.5 \\
3.6 \\
4.4\end{array}$ \\
\hline$(10 \stackrel{\mathrm{M}}{-} 20)$ & $\left.\begin{array}{l}\mathrm{A}(\text { less than } 1) \\
\mathrm{B}(1-2) \\
\mathrm{C}(2-3 \\
\mathrm{D}(\text { over } 3\end{array}\right)$ & $\begin{array}{r}77 \\
36 \\
6\end{array}$ & $\begin{array}{l}4.7 \\
5.5 \\
4.3 \\
4.5\end{array}$ & $\begin{array}{l}1.2 \\
0.9 \\
0: \mathrm{s} \\
0.5\end{array}$ & $\begin{array}{l}5.9 \\
6.45 \\
5.0\end{array}$ \\
\hline $\begin{array}{c}\mathrm{L} \\
(20-30)\end{array}$ & $\begin{array}{l}\mathrm{A}(\text { less than } 1) \\
\mathrm{B}(1-2) \\
\mathrm{C}(2-3) \\
\mathrm{D}(\text { over } 3\end{array}$ & $\begin{array}{r}36 \\
16 \\
11 \\
2\end{array}$ & $\begin{array}{l}6.0 \\
5.9 \\
7.5\end{array}$ & $\begin{array}{l}1 . \sigma \\
1.3 \\
0.5\end{array}$ & $\begin{array}{l}7.0 \\
7.6 \\
7.4 \\
8.0\end{array}$ \\
\hline $\begin{array}{c}\text { EL } \\
\left(\begin{array}{l}\text { over } 30 \\
\text { ) }\end{array}\right.\end{array}$ & $\begin{array}{l}\mathrm{A}(\text { less than } 1) \\
\mathrm{B}(1-2) \\
\mathrm{C}(2-3) \\
\mathrm{D}(\text { over } 3)\end{array}$ & $\begin{array}{r}14 \\
2 \\
1\end{array}$ & $\begin{array}{l}10.1 \\
10.113 .0 \\
16.0\end{array}$ & $\begin{array}{l}1.2 \\
3.3 \\
4: 0 \\
-\end{array}$ & $\begin{array}{l}11.3 \\
13.417 .0 \\
16.0\end{array}$ \\
\hline \multicolumn{2}{|l|}{ Total } & $281^{-}$ & 1.407 & 299 & 1.706 \\
\hline \multicolumn{2}{|c|}{ Average per farm } & & 5.0 & 1.1 & 6.1 \\
\hline
\end{tabular}


the farm to the collecting station, since those two factors are most closely related to every aspect of dairy farms, particularly to the hauling cost. The number of cows and heifers per farm are also shown in categories. On the average, a farm kept 5.0 milk cows and 1.1 heifers. The number of cows per farm does not change consistently with the distance from the collecting station. According to the statistics of Fukuoka Prefectural Government, the number of milk cows per dairy farm was 3.3 on the average of the whole prefecture in the same period.

Dairy farms are not so specialized in Japan as in most western countries. So is the case with this district. As for the farms investigated, on the average, about two thirds of farm land was arable, and about three fourths of the arable land was paddy used for rice culture. The acreage of farm land per farm was 2.23 hectares. Meadow or pasture was very scarce there being only about 0.24 hectares per farm. The acreage of arable land per farm did not vary consistently with the number of cows kept on the farm, but the acreage of pasture increased almost proportionately to the number of cows.

The number of workers per farm was 3.4 on the average, though not converted into man-equivalent. Out of them, 2.6 workers were the full-time, and 0.8 the part-time. There were no workers hired permanently here, while some workers were hired temporarily mostly for rice culture on about one fourth of the farms.

As for machinery, the so-called motorization was fairly advanced in this district. On most farms investigated, motor-tillers, motor-threshers, and motorchoppers were used, and on a little more than half of them, motor-sprayers and milkers were used. However, no farms had the "pipe-line milking system (parlor system)“. They shipped their milk in cans by small-trucks, light-vans, motorbicycles, bicycles, motor-tillers, or hand-carts. Cans of two different sizes were used. They were l-to and 5-sho cans. On the average, each farm had 2.43 cans of l-to and 2 cans of 5-sho.

\section{Milking and Cooling}

Milking was done twice or thrice a day. On most farms, milking was done between $5: 30$ and $7: 30$ in the morning, and between $6: 00$ and $8: 00$ or between 9:00 and 10:30 in the evening. On about two thirds of the farms, they milked in the afternoon, too. These milking times were decided according to: (1) other works of their farms, particularly, the busy time of rice culture in season, (2) for several months milking cows thrice a day after calving, and (3) the time schedule of the truck coming around to the collecting stations in the morning. Most of the farmers shipped their milk in the morning before the trucks came. In summer here, it is very hot and humid. Therefore, the shorter the time between milking and shipping, the better the quality of milk, because milk was not cooled at farm, even at collecting stations very well. Thus, some farmers want to milk late at night.

36.0 per cent of farms did not use milkers. They milked by hand. Most of them were small farms. They use buckets for milking, and poured it into cans. They cooled cans in various ways before shipping. There were 7 farms 
having refrigerators for tanks at their farms. About one third of the rest placed the cans in small water tanks with no cooling machines. The rest of two thirds brought their milk to collecting stations for cooling which was milked in the evening too, and they dipped their milk cans into the water cooled by the refrigerator by the next morning. Especially, in rainy and summer seasons, the cooling is big problems for farmers.

In these seasons, out of all investigated farmers, more than 86 per cent of farmers brought their milk again in the evening or in the night to coollecting station, 1.8 per cent of them cooled their milk can by hanging in the deep well, and 1.4 per cent of them use their home-refrigerator, for cooling, as shown in Table 3 .

Table 3. Cooling on farm.

(Percentage)

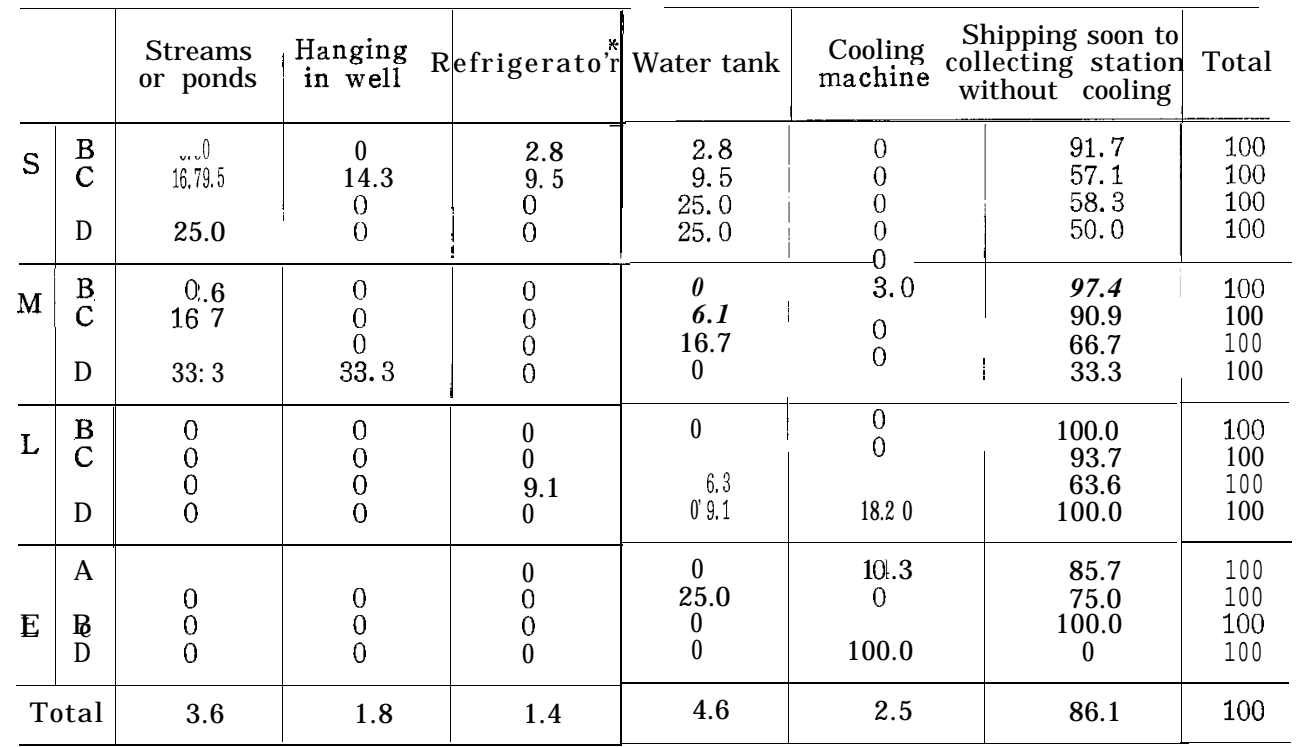

* The same kind as used for food. Only used in summer.

The more the amount of milk shipped, and the longer the distance from the farms to the collecting stations, the more the farmers brought their milk to the collecting stations for cooling.

\section{Transporting Facilities}

All farmers investigated shipped their milk to the collecting stations themselves by their own several kinds of vehicles. The number of farmers classified according to the kind of vehicles for shipping is shown in percentage in Table 4. Taking all farms investigated as 100, 32.7 per cent of them shipped their milk by motorbicycles, 19.6 per cent by bicycles, 16.0 per cent by light-vans, 12.5 per cent by hand-carts, 4.6 per cent by small-trucks, 2.0 per cent by motortillers, and 12.6 per cent by no vehicles at all, because they were located very 
Table 4. Kinds of vehicles used by farmers for shipping milk.

(Percentage in number of farms)

\begin{tabular}{|c|c|c|c|c|c|c|c|c|c|}
\hline & $\begin{array}{l}\text { Small- } \\
\text { truck }\end{array}$ & $\begin{array}{l}\text { Light- } \\
\text { van }\end{array}$ & $\begin{array}{l}\text { Motor- } \\
\text { bicycle }\end{array}$ & Bicycle & $\begin{array}{l}\text { Motor- } \\
\text { tiller }\end{array}$ & $\begin{array}{l}\text { Hand- } \\
\text { cart }\end{array}$ & $\begin{array}{l}\text { No } \\
\text { vehicle }\end{array}$ & Total \\
\hline Distance : & $\begin{array}{l}\text { A } \\
\text { B } \\
\text { C } \\
\text { D }\end{array}$ & $\begin{array}{r}2.7 \\
6.7 \\
13.8 \\
-\end{array}$ & $\begin{array}{r}7.3 \\
29.3 \\
24.1 \\
35.7\end{array}$ & $\begin{array}{l}19.4 \\
46.7 \\
55.2 \\
64.3\end{array}$ & $\begin{array}{l}1472050.98 \\
-\end{array}$ & $\begin{array}{l}1.3 \\
-2.4 \\
-\end{array}$ & $\begin{array}{l}- \\
-21.8 \\
-\end{array}$ & $\begin{array}{l}\text { "21.213 } \\
\text { - }\end{array}$ & $\begin{array}{l}\text { (10 10 10 1) } \\
100\end{array}$ \\
\hline Load Size: & $\begin{array}{c}\mathrm{S} \\
\mathrm{M} \\
\mathrm{L} \\
\mathrm{EL} \mathrm{L}\end{array}$ & $\begin{array}{r}1.4 \\
2.5 \\
9.2 \\
14.3\end{array}$ & $\begin{array}{r}2.7 \\
13.1 \\
32.3 \\
33.3\end{array}$ & $\begin{array}{l}44.6 \\
37.7 \\
20.0 \\
-\end{array}$ & $\begin{array}{r}31.1 \\
23.0 \\
4.6 \\
4.8\end{array}$ & $\begin{array}{l}\overline{-} \\
\overline{4.6} \\
9.5\end{array}$ & $\begin{array}{r}6.8 \\
13.9 \\
15.4 \\
19.0\end{array}$ & $\begin{array}{l}12.2 \\
10.7 \\
12.3 \\
28.6\end{array}$ & $\begin{array}{l}100 \\
100 \\
100 \\
100\end{array}$ \\
\hline \multicolumn{2}{|c|}{ Total } & 4.6 & 15.9 & 32.7 & 19.6 & 2.0 & 12.5 & 12.7 & 100 \\
\hline
\end{tabular}

near the collecting stations. The kind of vehicle varies according to the dis tance and the load-size as in Table 4.

In Table 4, bicycles are used for a short distance and a small load, rear-car? for a short distance, and a larger load. Motorbicycles are used for a longer distance, but a small load, and light-vans for a longer distance and a larger load. Small-trucks are the largest vehicles, but not always used by the farmers belonging to the class of the largest load size and the longest distance. Because, the farmers purchased the vehicle to use mainly for the other purposes, i. e., transportations of feeds, manures and others. Some farmers told us that smalltrucks were too big for their load size, and the transportation cost was high for shipping milk.

The average and the range of load size and distance of each class are shown in Table 5. The average load size was 18.131 tons per year, and the average hauling distance $0.977 \mathrm{~km}$.

Table 5. Distances and load sizes.

(Average for a farm)

\begin{tabular}{|c|c|c|c|c|c|c|c|c|c|}
\hline \multirow[b]{2}{*}{ Distance } & & $\begin{array}{l}\text { Small- } \\
\text { truck }\end{array}$ & $\begin{array}{l}\text { Light- } \\
\text { van }\end{array}$ & $\begin{array}{l}\text { Motor- } \\
\text { bicycle }\end{array}$ & Bicycle & $\begin{array}{l}\text { Motor- } \\
\text { tiller }\end{array}$ & $\begin{array}{l}\text { Hand- } \\
\text { cart }\end{array}$ & $\begin{array}{l}\text { No } \\
\text { vehicle }\end{array}$ & Average \\
\hline & $\begin{array}{l}\text { A } \\
\text { B } \\
\text { C } \\
\text { D }\end{array}$ & $\begin{array}{l}\mathrm{km} \\
0.600 \\
1.525 \\
2.275 \\
-\end{array}$ & $\begin{array}{l}\mathrm{km} \\
0.292 \\
1.164 \\
2.143 \\
5.125\end{array}$ & $\begin{array}{l}\mathrm{km} \\
0.498 \\
1.325 \\
2.081 \\
4.233\end{array}$ & $\begin{array}{l}\mathrm{km} \\
0.419 \\
1.155 \\
2.000 \\
-\end{array}$ & $\begin{array}{l}\mathrm{km} \\
0.480 \\
1.800 \\
2.000 \\
-\end{array}$ & $\begin{array}{l}\quad \mathrm{km} \\
0.178 \\
- \\
-\end{array}$ & $\begin{aligned} & \mathrm{km} \\
& 0.067 \\
& 1.000 \\
&- \\
&-\end{aligned}$ & $\begin{array}{l}\mathrm{km} \\
0.315 \\
1.259 \\
2.113 \\
4.508\end{array}$ \\
\hline \multicolumn{2}{|c|}{ Average } & 1.580 & 1.606 & 1.429 & 0.576 & 0.671 & 0.195 & 0.096 & 0.977 \\
\hline \multicolumn{2}{|c|}{ Range } & $3.8-2.5$ & 1. O-6.: & $0.2-6.0$ & $0.15 \sim 1.5$ & $0.3 \sim 0.8$ & $0.02-0.4$ & 0. O-O. 2 & 一 \\
\hline Load Size & $\begin{array}{c}S \\
M \\
L \\
E L\end{array}$ & $\begin{array}{r}\text { ton } \\
5.223 \\
12.561 \\
24.592 \\
50.290\end{array}$ & $\begin{array}{r}\text { ton } \\
6.871 \\
18.036 \\
25.496 \\
45.730\end{array}$ & $\begin{array}{r}\text { ton } \\
7.062 \\
14.708 \\
23.639 \\
71.026\end{array}$ & $\begin{array}{r}\text { ton } \\
6.676 \\
13.789 \\
22.258 \\
32.654\end{array}$ & 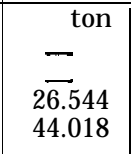 & $\begin{array}{r}\text { ton } \\
6.107 \\
15.741 \\
25.064 \\
48.584\end{array}$ & $\begin{array}{r}\text { ton } \\
5.720 \\
14.362 \\
23.596 \\
30.676\end{array}$ & $\begin{array}{r}\text { ton } \\
6.738 \\
14.808 \\
24.515 \\
45.845\end{array}$ \\
\hline \multicolumn{2}{|c|}{ Average } & 24.253 & 26.110 & 14.227 & 12.515 & 31.537 & 23.985 & 17.508 & 18.1.31 \\
\hline \multicolumn{2}{|l|}{ Range } & $6-49$ & $5-41$ & $4-26$ & $3-21$ & $14 \sim 29$ & $8 \sim 42$ & $5 \sim 35$ & 一 \\
\hline
\end{tabular}




\section{Handling at Collecting Stations}

Cooling machine was installed in all collecting stations under FFDC. The cooling machine can keep the temperature of water in the tank at $10^{\circ} \mathrm{C}$ while it works. All of them usually worked from March to December. The water tank had a capacity of 3.9-koku on the average. But the actual level was 1.83-koku per day. Such under-utilization suggests inefficiency in the operation of collecting stations.

Farmers ship their milk usually in the morning before the co-op truck comes. The "manager" at the collecting station checks the quantity of each farmer's milk, and tests it with alcohol. If the milk passes the test, it is poured into larger, 2-to cans of the co-op, and loaded on the truck when it comes. The farmers wash their cans and come home. The "manager" was hired as a parttime worker by the co-op. The milk shipped in the afternoon has to be kept cool in the water until the next morning.

In Kumamoto, all collecting stations investigated had bulk tanks. These tanks can store milk cooling. Under this system, milk is cooled at about $1^{\circ} \mathrm{C}$ or any desired level, and pumped up into a pick-up truck. The capacity of tank on the average for collecting stations investigated was 31. 7-koku, and all tanks were used at almost full capacity.

\section{Hauling from Collecting Stations to Plant}

The pick-up trucks of FFDC came around to all collecting stations, and collected the 2-to cans, and brought them to the plant, once a day. The pick-up route was 47.28 kilometers long, and included 4.2 collecting stations, and by which 2.006 tons of milk was hauled per day on the average. The loading and unloading of these cans were done by hand. The handling of the shipped milk at the plant was composed of the quality alcohol-inspection, dumping, weighing, can washing, and reloading of empty cans on the truck.

In Kumamoto, a tank truck ran 79.8 kilometers, and hauled 4.085 tons of milk per day on the average. Under the bulk hauling system, the operations performed at collecting stations by the driver of the truck are very simple. He only connects the pick-up tank to the storage tank with a hose. The milk was pumped up by a motor automatically.

\section{Hauling Cost}

The hauling cost per 1 kilogram of milk was 6.23 yen on the average for the entire hauling process. The price of milk purchased at the plant was determined every month. The price was 36.49 yen per 1 kilogram on the year average. Therefore, the hauling cost stands at 16.79 per cent of the price. Of course, the hauling cost is not only composed of money expenses. It includes the labor cost paid by farmer's own labor. Such labor cost was 2.26 yen out of 6.23 yen per 1 kilogram of milk. It was estimated with the wage rate of temporary hired workers in this district. The hauling cost at each stage is as follws:

Stage I: from farms to collecting stations.

Stage II: at collecting stations.

3.31 yen per $\mathrm{kg} 53.2 \%$

Stage III: from collecting stations to plant.

1.09

1.83

$17.5 \prime \prime$

Total

6.23

29.3 "

100.0 " 
Under the bulk hauling system in Kumamoto, the hauling cost was 0.78 yen per kilogram at stage II, and 1.03 yen per kilogram at stage III, respectively. Both were much smaller than their counterparts in Fukuoka. The detail of the hauling cost for each stage was shown in Tables 6, 7, and 8 .

Table 6. Hauling cost on first stage (yen per $1,000 \mathrm{~kg}$ of milk).

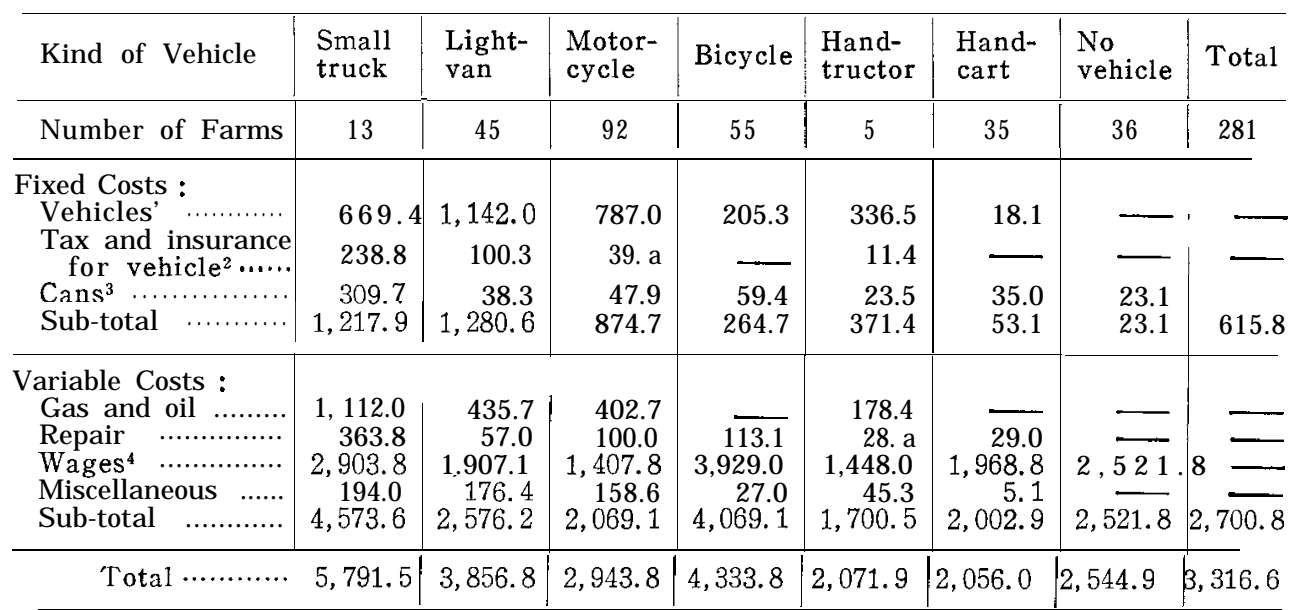

1, 3. Depreciation and interest (0.06). For the vehicles' depreciation, wheels, bodies, front tires and rear ones were estimated separately.

1, 2, 3. Hauling share was estimated through interviews.

4. Operator and his family's labor only. Estimated with the wage rate and labor hours of a temporary worker in every month. Labor hours included the time spent at the receiving station for handling, checking, and test.

Table 7. Hauling cost on second stage (yen per $1,000 \mathrm{~kg}$ of milk).

\begin{tabular}{|c|c|c|}
\hline & Can Hauling System & Bulk Hauling System \\
\hline $\begin{array}{l}\text { Fixed Costs : } \\
\quad \text { Building and equipment' } \\
\text { Land rent and taxes } \\
\text { Machinery } \\
\text { Sub-total }\end{array}$ & $\begin{array}{r}202.6 \\
33 . \mathrm{a} \\
391.7 \\
628.1\end{array}$ & $\begin{array}{r}156.4 \\
5.6 \\
* \\
162.0\end{array}$ \\
\hline 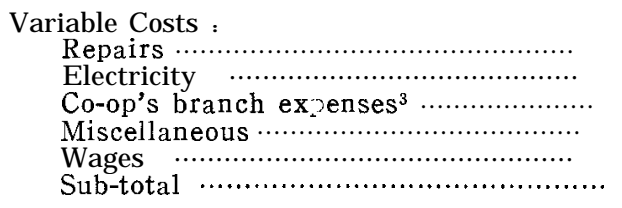 & $\begin{array}{r}27.3 \\
384.5 \\
33.0 \\
19.7 \\
\overline{464.5}\end{array}$ & $\begin{array}{r}44.8 \\
200.0 \\
63.8 \\
310.6 \\
619.2\end{array}$ \\
\hline Total $\ldots \ldots \ldots \ldots \ldots \ldots \ldots \ldots \ldots \ldots \ldots$ & $1,092.6$ & 781.2 \\
\hline
\end{tabular}

1, 2. Depreciation and interest (0.06).

3. Receiving stations are managed by the co-op's branches. Co-op's branches ran other businesses than hauling milk. Here, hauling share was estimated.

* This cost is included in the item of building and equipment. 
Table 8. Hauling cost on third stage (yen per 1,000 $\mathrm{kg}$ of milk).

\begin{tabular}{|c|c|c|}
\hline & Can Hauling System & Bulk Hauling System \\
\hline 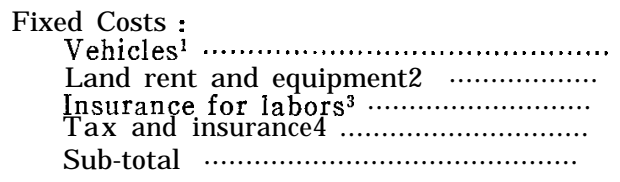 & $\begin{array}{r}201.0 \\
2 \mathrm{x} .4 \\
157.0 \\
50.8 \\
437.2\end{array}$ & $\begin{array}{r}323.5 \\
* * \\
449 \\
368: 4\end{array}$ \\
\hline 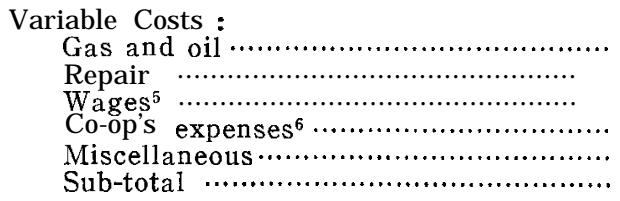 & $\begin{array}{r}78.2 \\
78.8 \\
442.0 \\
104.2 \\
32.2 \\
735.4\end{array}$ & $\begin{array}{r}190.5 \\
111.3 \\
246.8 \\
98.8 \\
13.6 \\
611.0\end{array}$ \\
\hline 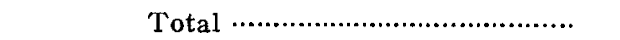 & $1,172.6$ & $1,029.4$ \\
\hline
\end{tabular}

1, 2. Depreciation and interest (0.06).

3 , 4, 5, 6. Hauling share estimated.

* This cost is included in the item of vehicle.

** This cost is included in the item of wages.

\section{ANALYSIS}

\section{Model of Average Cost Function}

The hauling cost at each stage depends on several factors, i. e., the kind of vehicle, the load size, the hauling distance, the size of collecting station and the volume of milk handled. The relationship between the hauling cost and these factors can be expressed in terms of the following average cost functions.

Stage I. For farms using vehicle $i(=$ small-truck, light-van, motorbicycle)

$$
C_{1 i}=a_{i}+b_{1 i} x_{1 i}+b_{2 i} x_{1 i}^{2}+c_{1 i} x_{2 i}+c_{2 i} x_{2 i}^{2}+u_{i}
$$

where, $C_{1 i}$ : hauling cost at Stage I from farm to collecting station per ton of milk per year (1,000 yen),

$x_{1 i}$ : volume of milk shipped from farm to collecting station per year (ton),

$x_{2 i}$ : distance from farm to collecting station $(\mathrm{km})$,

$a_{i}, b_{1 i}, b_{2 i}, c_{1 i}, c_{2 i}$ : parameters to be estimated,

$u_{i}$ : error term.

Stage II. Under the hauling system $j$ (=can hauling system, bulk hauling system)

$$
C_{\mathrm{Ilj}}=k_{j}+m_{1 j} \bar{x}_{1 j}+u_{j}
$$

where, $C_{\mathrm{II} j}$ : cost of handling at collecting station per ton of milk per year $(1,000$ yen),

$\bar{x}_{1 j}$ : volume of milk handled at collecting station per year (ton),

$k_{j}, m_{1 j}$ : parameters to be estimated,

$u_{j}$ : error term.

Stage III. Under the hauling system $j$ (=can hauling system, bulk hauling system) 


$$
C_{I I I j}=\alpha_{j}+\beta_{1 j} X_{1 j}+\beta_{2 j} X_{1}^{2}+\gamma_{1 j} X_{2 j}+\delta_{j} \frac{X_{3 j}}{R_{j}}+\nu_{j}
$$

where, $C_{1 ! l j}$ : hauling cost from collecting stations to processing plant per ton of milk per year (1,000 yen),

$X_{1 j}$ : volume of milk hauled per route (ton),

$X_{2 f}$ : distance traveled per truck $(1,000 \mathrm{~km})$,

$X_{3 j}$ : number of collecting stations per route,

$R_{j}$ : number of routes, given $(=25)$,

$\alpha_{j}, \beta_{1 ;}, \beta_{2}, \gamma_{1 j}, \delta_{j}$ : parameters to be estimated,

$\nu_{j}:$ error term.

By summing up the above equations, we may derive an aggregate hauling cost function covering the whole process of hauling as follows:

$$
C_{T}=C_{\mathrm{Ij}}+C_{11 j}+C_{\mathrm{IIIj}}
$$

where, $C_{T}$ denotes the aggregate average hauling cost, $C_{1}$ the cost function on Stage I, $C_{I I j}$ the cost function on Stage II and $\mathrm{C}_{\mathrm{III}}$ the cost function on Stage III.

In the equation (4), some variables are related with each other by their definitions as follows:

$$
\begin{aligned}
& \bar{X}_{1}=\frac{n x_{1}}{X_{3}}, \\
& X_{1}=\frac{n x_{1}}{R_{3}} .
\end{aligned}
$$

where, $n$ is the total number of dairy farms, given $(=885) . \quad x_{2}, X_{2}$, and $X_{3}$ are closely related with each other. From the investigated data, we derived the following equations.

$$
\begin{array}{cc}
\boldsymbol{x}_{2}=6.5124-0.02887 X_{3} & \boldsymbol{R}^{\prime}=\mathbf{0 . 7 4 0 8} \\
(0.01207) & \\
\mathrm{X},=48.6572-8.72774 X_{3} & \boldsymbol{R}^{\prime}=\mathbf{0 . 9 9 4 5} \\
(\mathbf{0 . 6 7 6 7 5 )} &
\end{array}
$$

Using these relations, several variables in equation (4) can be eliminated. Thus, we will obtain $C_{T}$ as a function of two variables, $x_{1}$ and $X_{3}$ for farms using vehicle $\mathbf{i}$, and for hauling system $\mathbf{j}$.

$$
C_{T i j}=k i j+p i j x_{1}+q i j x_{1}^{2}+r i j X_{3}+s i j X_{3}^{2}+t i j\left(\frac{x_{1}}{X_{3}}\right)
$$

\section{Estimation of Farameters}

\section{Stage I.}

Light-van; $C_{\mathrm{I}}=3.56820-0.15201 x_{1}+0.00172 x_{1}^{2}-0.01514 \mathrm{x},+0.00052 x_{2}^{2} \cdots \cdots(6)$

(0.05863) (0.00070) (0.01001) (0.00032)

$$
R:=0.9556
$$

Motorbicycle ; $C_{\mathrm{I}}=4.44930-0.38994 \mathrm{x},+0.00784 x_{1}^{2}+2.90170 \dot{x}_{2}-0.31773 x_{2}^{2}$ $(0.18670)(0.00744) \quad(0.89543) \quad(0.11738)$

$$
\text { (7) } \quad R^{2}=0.9390
$$


Small-truck; $C_{1}=4.16500-0.33374 x_{1}+0.00398 x_{1}^{2}+0.62126 x_{2}^{2}$

$$
(0.21125)(0.00363)(0.23233)
$$

Stage II.

$$
R^{3}=0.9366
$$

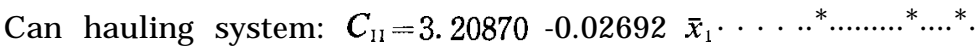

(0.00725)

$$
R^{2}=0.6324
$$

Bulk hauling system; $C_{11}=2.31900-0.00087 \bar{x}_{1} \ldots \ldots$..*

$$
(0.00026)
$$

$$
R^{2}=0.7343
$$

Stage III.

Can hauling system; $C_{\mathrm{II}}=1.48870-0.00150 \mathrm{X},+0.000000415 X_{1}^{2}+0.16264 X_{2}$

$$
\begin{gathered}
(0.00053) \quad(0.000000213) \quad(0.10052) \\
+0.00334\left(\frac{X_{3}}{R}\right) \ldots \ldots \ldots \ldots \ldots \ldots \ldots \ldots \ldots \ldots \ldots \ldots \ldots \ldots \ldots \ldots \ldots \ldots \ldots \ldots \\
(0.00167)
\end{gathered}
$$

Bulk hauling system; $C_{111}=0.57332-0.00049 \mathrm{X},+0.000000177 X_{1}^{2}+0.02868 X_{2}$

$$
\begin{array}{lll}
(0.00059) & (0.000000149) & (0.00942) \\
R^{2}=0.6956 &
\end{array}
$$

From these equations, the following aggregate hauling cost functions are derived. Can hauling system:

Light-van; $C_{T}=16.05841-0.20512 x_{1}+0.00224 x_{1}^{2}+1.41948 X_{3}-23.82420 \frac{x_{1}}{{ }_{3} \boldsymbol{V}}$

Small-truck; $C_{T}=43.12439-0.38685 \mathrm{x},+0.00450 \mathrm{x}, 2+1.30270 X_{3}-23.82420 \frac{x_{1}}{\mathrm{AS}_{2}}$

Motorbicycle; $C_{T}=35.95730-0.44305 x_{1}+0.00836 x_{1}^{2}+1.39545 X_{3}-23.82420-\frac{x_{1}}{X_{3}}$

Bulk hauling system :

Light-van; $C_{T}=7.77963-0.16936 x_{1}+0.00194 x_{1}^{2}+0.23393 \mathrm{X},-\mathrm{O} .76553 \frac{x_{1}}{X_{3}}$

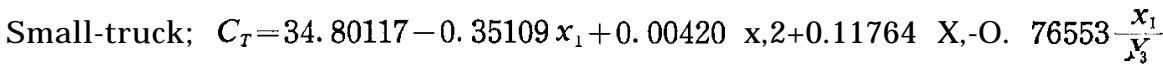

Motorbicycle; $C_{T}=14.15876-0.40729 x_{1}+0.00806 x_{1}^{2}+0.21040 X_{3}-0.76553 \frac{x_{1}}{X_{3}}$

\section{Estimation of Optimums}

The estimation to get two kinds of optimums stated in II, the purpose of the study, were done of the three groups of farmers which use light-van, smalltruck and motorbicycle. Using the average cost functions on three stages, we obtained the aggregate average cost function of whole processes for both haul- 
ing systems of the can and the bulk as follows.

Using the aggregate cost functions, we can estimate the two optimums (i) and (ii) as stated above.

(i) Let $x_{1}$ take the magnitude of the current amount of milk shipped from a farm on the average, and differentiate the functions with respect to $\mathrm{X}$,. Let the derivatives be equal to zero, examining the second order derivatives, and we can get the optimmum $X_{3}$ to minimize $C_{T}$ under the current $x_{1}$.

(ii) Differentiate the functions with respect to $x_{1}$ and $X_{*}$, and let the derivatives be equal to zero respectively, examining the second order derivatives. Thus, we can get the optimums of $x_{1}$ and $X_{3}$ to minimize $\mathrm{C}$,

The results are as follows (Tables 9, 10):

Table 9. Optimum number and size of collecting stations to minimize hauling cost under current amount of milk shipped.

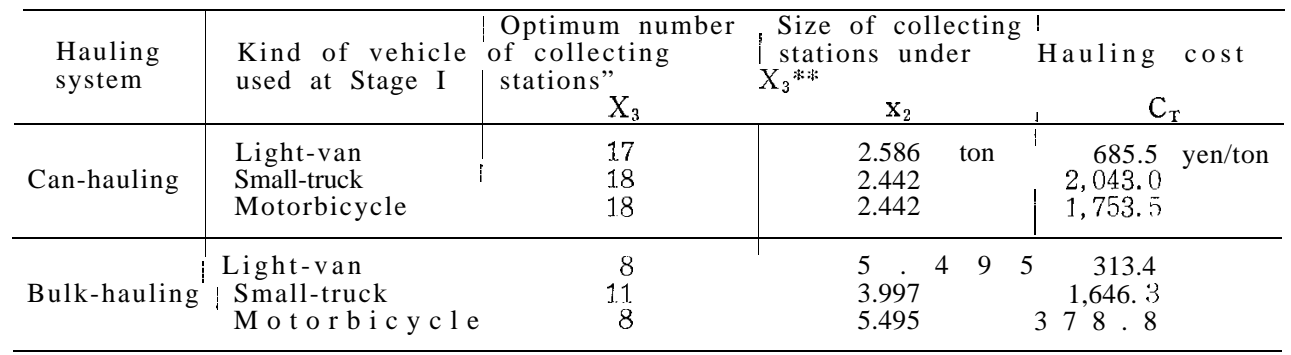

* Current number of hauling stations is 127 .

$* * \overline{\mathbf{x}}_{2}$ : Current amount of milk shipped $\div \mathrm{X}_{3} \div 265$.

The current size of a collecting station was 0.7336 tons on the average, and the current amount of milk shipped per day per station was 0.3433 tons on the average.

Table 10. Optimum number and size of collecting stations, and optimum amount of milk shipped to minimize hauling cost.

\begin{tabular}{|c|c|c|c|c|c|}
\hline $\begin{array}{l}\text { Hauling } \\
\text { system }\end{array}$ & $\begin{array}{l}\text { Kind of vehicle } \\
\text { used at Stage I }\end{array}$ & \begin{tabular}{|} 
Optimum number \\
of collectingrr \\
stations \\
$\mathrm{X}_{3}$
\end{tabular} & \begin{tabular}{|l} 
Size of collect- \\
ing stations \\
under $X_{3}$ and $\mathbf{x}_{1}$ \\
$\overline{\mathbf{x}}_{2}$
\end{tabular} & $\begin{array}{l}\text { Optimum amount } \\
\text { of milk shipped } \\
\text { per farm per year } \\
x 1\end{array}$ & $\begin{array}{l}\text { Hauling } \\
\text { cost } \\
\mathrm{C}_{\mathrm{T}} \\
\end{array}$ \\
\hline $\begin{array}{l}\text { Can- } \\
\text { hauling }\end{array}$ & $\begin{array}{l}\text { Light-van } \\
\text { Small-truck } \\
\text { Motorbicycle }\end{array}$ & $\begin{array}{ll}39 & \text { I } \\
45 & \end{array}$ & $\begin{array}{l}\text { ton } \\
1.127 \\
0.977 \\
1.293\end{array}$ & $\begin{array}{r}\text { ton } \\
107.30 \\
126.33 \\
62.48\end{array}$ & $\begin{array}{l}\text { yen/ton } \\
107.1 \\
458.8 \\
550.7\end{array}$ \\
\hline $\begin{array}{l}\text { Bulk- } \\
\text { hauling }\end{array}$ & $\begin{array}{l}\text { Light-van } \\
\text { Small-truck } \\
\text { Motorbicycle }\end{array}$ & $\begin{array}{l}18 \\
10\end{array}$ & $\begin{array}{l}3.140 \\
2.442 \\
3.848\end{array}$ & $\begin{array}{l}91.67 \\
89.55 \\
48.07\end{array}$ & $\begin{array}{r}74.4 \\
40.2 \\
241.9\end{array}$ \\
\hline
\end{tabular}

* Current amount of milk shipped per farm on the average was 18.131 tons per year.

Using the results shown in Table 9, we caculated the optimum number and size of collecting stations to minimize the hauling cost under various amount of milk shipped for the practical purpose. The results are shown in Table 11. 
Table 11. Optimum number and size of collecting stations to minimize hauling cost under possible various amount of milk shipped.

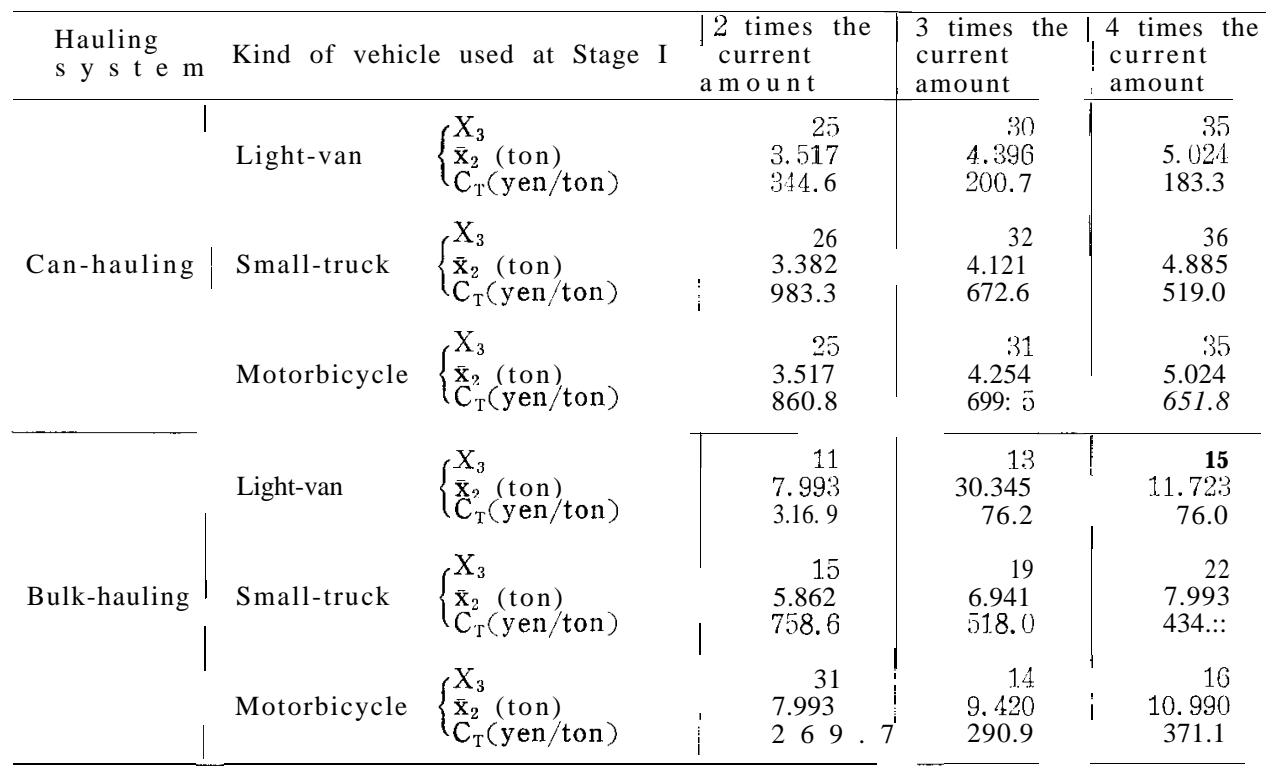

\section{CONCLUSION}

In this study, 281 dairy farms, 67 collecting stations and 15 pick-up routes of a milkshed under Fukuoka Federation of Dairy Co-operatives which was shipping milk to Yukijirushi (Snow Brand) Milk Company Ltd. were investigated to analyze the hauling cost. In this milkshed, there were 885 dairy farms, 127 collecting stations and 25 pick-up routes. This milkshed was under the canhauling system. In order to infer the effect of introducing the bulk-hauling system into this milkshed, a milkshed in Kumamoto Prefecture was investigated, where the bulk-hauling system was adopted. The main results of the study were as follows:

(1) The hauling cost of milk from farms to the processing plant under the can-hauling system was 6,230 yen per ton, or 16.2 per cent of the f. o. b. milk price at the plant. (In the United States, the percentage was 5.0 under the canhauling system in 1957. Sidney Ishee and W. L. Barr: "Effects of Bulk Milk Assembly on Hauling Cost." The Pennsylvania State University, College of Agriculture and Experiment Stations, Bulletin No. 641, 1958.) Under the bulkhauling system, the hauling cost was estimated as 5,118 yen per ton, or 13.3 per cent of the f. o. b. milk price at the plant. If the amout of milk shipped increases, the hauling cost can be cut down much by substituting the bulkhauling system for the can-hauling system.

(2) Under the current amount of milk shipped, the collecting stations will have to be reduced from the current number 127 to $17 \sim 18$ under the can-hauling system, and 8 11 under the bulk-hauling system, to minimize the hauling cost. The hauling cost minimized will be about 1,494 yen per ton under the can-haul- 
ing system, and about 446 yen per ton under the bulk-hauling system.

(3) Assuming that both the number of collecting stations and the amount of milk shipped can be changed, the former will have to be reduced to 34-45 under the can-hauling system, and 10 14 under the bulk-hauling system, and the latter will have to be increased to 62.43-107.30 tons per farm per year under the can-hauling system, and 48.07-91.67 tons per farm per year under the bulk-hauling system, to minimize the hauling cost, while the current amount of milk shipped was 18.13 tons per farm per year.

(4) Even though the amount of milk shipped increases considerably, the current number of collecting stations will be too large. For instance, the amount of milk shipped increases to 2-4 times the current amount, the current number of collecting stations will have to be reduced to 25-36 under the can-hauling system, and 11-22 under the bulk-hauling system to minimize the hauling cost. 